UDC 330.1:316.3-043.86]:001.32(477)

DOI: https://doi.org/10.26661/hst-2019-2-79-11

\title{
POSITION AND ROLE OF MODERN ECONOMIC EDUCATION AS THE MAIN MEGATREND OF INNOVATIVE DEVELOPMENT OF UKRAINE
}

\author{
COLEKSENKO, ROMAN \\ E-mail: roman.xds1@ukr.net ORCID iD: https://orcid.org/ 0000-0002-2171-514X \\ Dmytro Motornyi Tavria state agrotechnological university (Melitopol, Zaporizhzhia obl., \\ Ukraine) \\ B.Khmelnytsky av. 18, 72312 Melitopol, Zaporizhzhia obl., Ukraine
}

\begin{abstract}
.
The relevance of the research lies in systematic comprehension and strategic solutions to problems associated with economic education of modern youth. In the conditions of digitalization for our country is the main in training highly qualified personnel for the real sector of the economy - the formation of youth readiness for adaptation in the socio-economic rapidly changing world. This problem can be solved on condition that the young people form and develop entrepreneurial abilities, which will ensure the achievement of real success in any area of their chosen professional activity.

The aim of the article is to define the position and role of economic education as the main megatrend of innovative development of Ukraine. The objectives of the research are: 1) to explore the human phenomenon of economic and its role in the modern life of the country; 2) to identify problem components of education in the formation of market consciousness of young people; 3 ) to propose ways to develop domestic economic education in the formation of creative economic education and culture of modern youth.

Methodology of research. As a result of the research on this problem the following methods of scientific research were used: Dialectical, abstractly logical, monographic and other methods of scientific research.

The specific methodology of education analysis gave rise to the beginning of the scientific tradition to consider education as a factor of social transformation. The results of the research. General and professional economic education today for any society, especially transformational, is a key factor in ensuring its innovative development in the framework of the latest global trends.

This, in turn, actualizes the problem of diversification and variety of forms, methods and organizational forms of providing Ukrainian citizens with high-quality educational services in the field of economic sciences and academic disciplines. The development of the economic system of the domestic national society directly depends on whether the Ukrainian educational community is able to develop adequate mechanisms for the formation of a high level of economic and entrepreneurial culture of the modern type among young people. At the same time, real economic processes definitely influence the economic socialization of young people and the level of their economically entrepreneurial education and politeness.

Keywords: economic education, economic consciousness, creativity, culture, innovative development, entrepreneur.
\end{abstract}

Position and role of modern economic education as the main megatrend of innovative development of Ukraine 
Statement the problem in general and linking it to important scientific or practical tasks. The phenomenon of the modern economic person supposes a high level of social and economic, civil, personal and moral culture and consciousness, which means the necessity of a high level of economic education and upbringing in the society, where innovative bases for the formation of entrepreneur as a new economic elite of the newest formation are provided. In Ukraine, as a country of transformation type, so far there is only the process of formation of economic education, which is necessary for the full development in the mass and professional consciousness of the elements of economically-entrepreneurial culture of modern character. In Ukraine, as a country of transformation type, so far there is only the process of formation of economic education, which is necessary for the full development in the mass and professional consciousness of the elements of economically entrepreneurial culture of modern character. This extremely actualizes the conceptual, theoretical, philosophical and worldview analysis of the development of economic education in our country as one of the main means of establishing the worldview of the modern entrepreneur.

Analysis of recent studies and publications, from which the solution of this problem was started and on which the author relies. In the given scientific research the ideas of the following domestic and foreign scientists are used: В. Андрущенка, В. Воронкової, Ф. Зеєра, П. Кубрушка, В. Ледньова, Г. Мухаметзянової, Р. Олексенка, В. Приходька, В. Іщенка, 3. Сазонової, Ю. Левицького, І. Лікарчука, В. Боброва, В. Гейця, В. Євтушевського, А. Мазаракі, C. Мочерного, А. Шегди, Е. Герасимової and other scientists.

Identification of previously
unresolved parts of the general
problem to which this article is devoted. In the modern world, a person of any profession and sphere of activity has the necessity to form a rather high level of economic education, culture and consciousness, which especially concerns those who have chosen the sphere of entrepreneurial activity for their professional self-realization. The social and economic sphere of life of the general public system in the global information world dominates over others, which requires the formation of a certain level of economic knowledge, values, guidelines and skills for the adequate orientation of a person in the civilizational and sociocultural space.

Human activity runs in the social space, where it, as a subject, is characterized, in particular, by forms of inclusion in economic activity. Deployment of the subject in the process of economic socialization predetermines the formation of a person's social and economic guidance, orientation to certain economic values, professional knowledge and skills, and other psychological qualities acquired by 
the individual in preparation for economic activity. Activity of the person in economic sphere, its selfrealization throughout the life depends on success of economic socialization.

The aim of the research is the process of formation of economic consciousness in modern youth in the context of modern economic education as the main megatrend of the country's development.

The objectives of the research are: 1) to study the human phenomenon of economic and its role in the modern life of the country; 2) to identify problem components of education in the formation of market consciousness of young people; 3 ) to propose ways of development of domestic economic education in the formation of creative economic education and culture of modern youth

Methodology of research. As a result of the research on this problem the following methods of scientific research were used: Dialectical, abstractly logical, monographic and other methods of scientific research. The specific methodology of education analysis gave rise to the emergence of the scientific tradition to consider education as a factor of social transformation.

\section{Presentation of the main research material with substantiation of the scientific results received.}

The Ukrainian educational community and the general public today face an important task of creating appropriate conditions for educational and politeness and worldview and moral socialization of young people to the complex economic conditions of modern global information world functioning.[2]

Modern economic education, both general and professional, is a necessary condition for formation of personal and professional competences of a person, which are necessary for all-round self-realization in conditions of globalization information and innovation trends. [1] At the same time, such education should not only be specifically specialized, but also have a general worldview and personal forming character.

"In the conditions of globalization of information and innovation tendencies and creation of the system of continuous education the problem of formation of the modern specialist's personality, education in him the qualities of a business man, characterizing the possibilities of personal potential in social and public, state and political, production spheres, acquires priority importance. Consequently, there is a need for rethinking and theoretical and methodological grounding of the process of training future specialists, in particular, economic profile" $[5, \mathrm{p}$. 176]. Indeed, the economicpedagogical community as one of the key elements of the Ukrainian educational system today should make extraordinary efforts to provide methodological, educational, competent and forming, world-view

Position and role of modern economic education as the main megatrend of innovative development of Ukraine 
and value unity in teaching disciplines of economic profile for future specialists of entrepreneurs, as well as for specialists in other areas of professional activity.[3]

Scientists emphasize that «in the new socio-economic and sociocultural conditions of existence of independent Ukraine education in the economic sector should be directed not only to the formation of a certain number of competencies, but also to the education of future specialists aspiration for activity in the economic sector, the formation of an independent and careful owner, who feels the need for personal economic culture, innovative application of knowledge in practice, in striving for business success» [4, pp. 49 - 50].

In countries with a developed form of market economy, economic education, enlightenment and upbringing is a necessary condition and an essential component of the functioning of the national socioeconomic system. A high level of economic education, culture and consciousness is ensured both by the presence of modern economic reality and by developed economic education, while in transformational societies, particularly in Ukraine, these two elements are in their infancy. "The transition of our country to a market economy raises an actual problem of modern times" formation of readiness of youth and students for adaptation in the conditions of social and economic life, which is changing. This problem can be solved only if young people develop entrepreneurial skills, which will ensure real success in any field of professional

activity.

The

particularities of the modern adaptation process in Ukraine are caused not only by the deep transformation of the whole structure of the society, radical change in the forms of ownership, formation and development of market relations, which determine qualitative changes in the social and economic behavior of people, but also by the high degree of instability of the environment itself, the rates of change of which do not always take into account the adaptive abilities of the population» [19, p. 13].

Professional economic education today must be formed in close connection with entrepreneurial specific activities, which will ensure the full socialization of the enterprising youth in the conditions of ultra-fast changes in the social and economic life of the transformation society of globalization. «One of the important aspects of the theory of formation and development of economic knowledge, which, in fact, indicates its content, is professional training. It is this theory that is one of the main elements in building an effective system of economic education of the person. Economic education allows to reveal a certain level of providing the person with the knowledge necessary for the formation of moral and economic features of the student, preparing him for educational and cognitive and economic and household activities»» $[13$, p. 56].

Further, it is on the creative and innovative abilities of the very person will directly depend on the success of her professional entrepreneurial 
activity. At the same time, it is necessary to clearly realize that it is education, including general and professional-economic education, that is called to develop in a person a transformative attitude to reality, creative attitude to everyday and professional self-realization, which is a necessary condition for successful entrepreneurship in the conditions of market economy development.

Thusly, in the formation of a young market economy, when the global trends are dictated by global knowledge principles, conceptual and theoretical analysis of the national education system is extremely relevant. In this connection, we consider it necessary to focus on the analysis of the modern state and the main contradictions of economic education in Ukraine.

The social changes that have taken position in our country predetermine significant prospects in the life of the Ukrainian people, the revaluation and renewal of all spheres of its activities, including science, education and culture. One of the main directions of such renewal is the search for new means of formation of qualified specialists for all sectors and, first of all, specialists in economics, who will be able to organize and implement such economic and social transformations in the near future, which will allow Ukraine to become one of the developed European states. "At the present stage, higher educational institutions that train economists must more thoroughly solve the actual problems of improving their professional training, focus their efforts on improving the content of education, introducing new, more effective methods, forms and means of training organization into the educational process, and on forming an active creative attitude to economic activity in future specialists. The urgent growth of requirements for the training of economists specialists, who will be responsible to the people for the recognition of the state in the civilized world, is dictated by time itself» $[20$, p. 175].

Hence, the urgent need for a worldview of values, scientific and methodological, instrumental innovative improvement of economic education in our country, as well as overcoming key contradictions in its structure, which, in our opinion, arise primarily because of the inconsistency of objective economic reality that exists in Ukraine, and leading theoretical developments of entrepreneurial activity in the market economy and global development.[15]

It should be noted that the general disadvantages of modern Ukrainian economic education, which require immediate intervention, are as follows:

- lack of long-term traditions of management studies;

- detachment from the real needs of economic activity;

- insufficient level of training of specialists in mastering the methods of economic and mathematical analysis;

- failure to take into account the requirements of the labor market in the preparation of specialists of economic direction; 
- low average quality of students' training;

- discrepancy to the world level of training of specialists in the overwhelming majority of higher educational establishments $[11, \mathrm{p}$. 131].

As the analysis shows, there are many dysfunctional and contradictory phenomena in the state of the national economic education, the fundamental reasons for which, in our opinion, are both the insufficient ideologically principled and scientificmethodological formation of the national economic education, and the discrepancy between the real objective forms of the economically entrepreneurial activity of Ukraine and the market and economic realities on which the Western economic education and science are oriented, as well as the lack of entrepreneurship.[16]

Another important contradiction of the national economic education is its attempts to use innovative and humanistic methods to form a strong personality of an entrepreneur, while the real conditions of the "uncivilized" market require from an entrepreneur not so much knowledge, skills and high morals, but the ability to twist and adapt to the corrupt economic and state environment. This contradiction can be resolved only in the conditions of reforming and establishment of the national market economy, when a truly modern subject of entrepreneurial and socio-cultural activity should be formed. "The market economy of modern Ukraine needs such a subject of economic relations who has personal features consistent with the principles of liberalization of production, finance and priority of private property" [12, p. 211]. It is on the basis of such values and guidelines, from our point of view, to overcome the above mentioned contradictions of the national economic education as well as to promote active and creative socialization of Ukrainian youth to new economic and entrepreneurial realities. "Economic socialization of a person is seen as a process of entering the younger generation to the economic sphere of society, and formation of economic thinking, as a process of Interiorization of the new reality, which includes knowledge of economic reality, mastering of economic knowledge, acquiring skills of economic behavior. In this context, the process of formation and development of a certain type of personality in accordance with the needs and requirements of the socioeconomic sphere of society " [8, p. 7]. Taking this into account, in the structure of economic education, both general and professionally entrepreneurial, it is necessary to provide substantial elements aimed at world-view-value and competence preparation of young people to the economic realities of the transformation society, as well as to prepare future entrepreneurs for competent overcoming contradictions.

After all, it is economic education that is a social subsystem in which the mismatch between the sphere of knowledge and values and objectively real conditions is overcome in the most active and most adequate way. It is economic education that today in 
our country is entrusted with the task of educating not only professionals of entrepreneurs, but also people with high personal and spiritual abilities and creative will. "In the context of the theory of human capital, education is seen as preparation of people for labor realization, so preference is given to professional subjects. From the point of view of human development, education is of independent value because, together with professional subjects, humanities disciplines become important as a means of a deeper understanding of natural and social phenomena, the position of a person in life" $[6, \mathrm{p}$. 123]. It is the potential of overcoming through economic education and enlightenment of the gap between the consciously desirable reality and the available objective reality that gives rise to many hopes, because this is what determines the ability of future generations to actively creative, creatively innovative self-realization in the economic, business and management sphere.

To resolve such fundamental and strategic tasks, which are formulated above, it is necessary, in our opinion, to theoretically and paradigmatically conceptualize the prospects and main directions of development of economic education, to diagnose and to forecast opportunities for development of this educational sphere in a creatively innovative way. The main thing, of course, should be a strategic priority of preparing young people for professionally competent business activities and actively innovative economic socialization in the conditions of globalization and transformation trends. "The main tasks of higher educational institutions, which train specialists in economic profiles, are to ensure that graduates master the system of knowledge and skills to solve certain typical tasks of activity in the process of performing these production functions, the transformation of necessary economic knowledge into economic thinking, the development of important personal qualities that increase the adaptation of young people to professional activity" [10, $\mathrm{p}$. $155]$.

Harmonious combination of professional competence and human values, understanding of economic regularities and socio-cultural trends is a key priority of the national economic education, especially in conditions when future entrepreneurs after education will meet the complex realities of the transformation society.

The most important direction in the development of economic education, which should be prospectively diagnosed and predicted, as well as to develop in every possible way, is the formation in the minds of the population, especially the future specialists of entrepreneurs, a deep understanding of the world-view value, fundamentally phenomenological significance of economic knowledge and beliefs, high entrepreneurial competence in the structure of personality of each person. "The task of training economists is to ensure that the choice of profession is a logical consequence of the gradual

Position and role of modern economic education as the main megatrend of innovative development of Ukraine 
increase in the level of professional orientation. In order to develop the professional orientation, it is necessary to organize the activities of future managers in such a way that they would actualize the contradictions between the requirements of the proposed activity and its personal importance for the person" [9, p. 375].

Building an economic education that harmoniously combines professional management and entrepreneurial competencies based on personal values is possible only under conditions of application of the leading innovative humanistic methods of teaching highly qualified educational community.

In this regard, there is an urgent need for the scientific and pedagogical community to develop methods of innovative humanistic plan adequate to the existing socio-economic reality, which would be aimed at the development of modern, high-quality world-view of values, personal professional and entrepreneurial competencies. From our point of view, both the competitiveness of the domestic economic education itself and its development and reform depend on it. There is a need to search for new models and approaches to professional training of future specialists, in particular, the economic profile, the quality of knowledge and skills of which largely depends on the economic development of our country. Under such conditions, rethinking the content, forms and methods of professional training of future economists, directing it to the modern social and economic realities is of great national importance. An essential component of the professional training of specialists in the economic profile is their psychological and pedagogical education, because the professional activity of these specialists is largely related to professional and personal communication, the ability to overcome conflicts, the ability to selfregulate, self-control, selfdevelopment, organizational activities, creative solutions to professional problems. Therefore, psychological and pedagogical training of future specialists of financial and economic profile is one of the decisive conditions for increasing the effectiveness of their future professional activity" [17, pp. 171 - 172].

After all, a very important further step in the establishment and development of continuing economic education is a problem of the diversification and diversity of forms of teaching in the system of lifelong learning, which should provide as many learning actors as possible with the opportunity to improve their entrepreneurial professional and cultural and economic competence.

"To increase the level of social responsibility of modern business, it is necessary to form and develop in entrepreneurs and the population spiritual, corporate, innovative, national, professional and other types of cultures through training, business games, mini pedagogical workshops, provision of appropriate scientific and advisory services, etc." [18, p. 170].

Therefore, the scientific and pedagogical community of economic 
profile in our country faces the actual problem of theoretical development and practical introduction of a diverse and formal economic life-long learning system [14].

After all, one of the main tasks of any specialized type of educational activity, and especially economic in the modern global financial world, is to develop a creatively innovative type of thinking in the personality, which should contribute to the active socialization of young people in a dynamic sociocultural change. In accordance with this, education should be aimed at developing an innovative style of thinking in young people, which is necessary for orientation in a rapidly changing business environment, for the ability to make risky effective decisions, as well as for the flexibility of entrepreneurial thinking. "Today, too, many young people are not prepared to live in a situation of rapid change. Objectively, this is caused by the new conditions that have emerged as a result of the formation of market economic relations and determine the emergence of new social norms and standards of behavior" [7, p. 49].

In this connection, the task of educating the entrepreneurial personality at a young age is extremely relevant. This task is set before the Ukrainian economic and pedagogical community to develop methods of training and education, which, on the one hand, would use the latest achievements of world economic thought, and on the other take into account the socio-economic realities that are emerging in our country in a transformational society.

\section{Список використаних джерел}

1. Волков, О. Г., Землянський, А. М., Олексенко, Р. І., Рябенко, С. М. (2017). Філософія: навчальний посібник-практикум.Мелітополь: МДПУ імені Богдана Хмельницького. 272.

2. Воронкова, В. Г., 2013. Формирование нового мировоззерния, нового человека, нового общества будущего. Антропологічні виміри філософських досліджень. Дніпропетровськ. 3. 79-80.

3. Воронкова, В. Г., 2008. Гуманізація освіти, науки, політики, влади, суспільства. Ін-т вищої освіти АПН України, Наи пед. ун-т ім. М.П. Драгоманова. К.: Вид-во НПУ імені М. П. Драгоманова. 1-2(7). 204-220.

4. Гіптерс, 3., 2005. Виховання діловитості і творчості майбутніх фахівців економічного профілю. Рідна школа. 12. 49 - 52.

5. Горбуліч, I. О., 2011. Формування готовності до ділового спілкування у майбутніх маркетологів. Вісник Луганського національного університету імені Тараса Шевченка (педагогічні науки). № 15 (226), серпень, частина II. 176 - 182.

6. Гурова, Ю. С., 2007. Розвиток людського ресурсу і міжнародна конкурентоспроможність країн. Дисертація на здобуття наукового ступеня кандидата економічних наук. Спеціальність 08.05.01 - світове господарство і міжнародні економічні відносини.К., 190.

7. Дембицька, Н., 2008. Соціально-психологічні проблеми економічної соціалізації молоді. Соціальна психологія. 2 (28). 49 - 59.

8. Економічна соціалізація молоді: соціально-психологічний аспект (2008) / загальна редакція В. В.Москаленко. К.: Український иентр політичного менеджменту, 336.

Position and role of modern economic education as the main megatrend of innovative development of Ukraine 
9. Ковальова, Г. М., 2008. Формування професійних якостей сучасного економіста освітнім середовищем. Наукові пращі Донецького національного технічного університету. Серія: Педагогіка, психологія і соиіологія. Донецьк: ДВНЗ «ДонНТУ», 2 (133). $374-375$.

10. Кремень, В. М., 2011. Особливості професійної діяльності фахівців 3 фінансів. Проблеми і перспективи розвитку банківської системи України. Збірник наукових праць. Суми: ДВНЗ «Українська академія банківської справи» НБУ. 31. 145 156.

11. Куклін, О. В., 2008. Становлення системи економічної освіти в Україні у контексті Болонського процесу. Вісник Черкаського університету. Науковий журнал. Серія: Педагогічні науки. Черкаси: ЧНУ імені Богдана Хмельницького. 120. 127 - 133.

12. Лавренко, О. В., 2011. Економічні настановлення як чинник становлення суб'єкта економічної соціалізації. Проблеми загальної та педагогічної психології. Збірник наукових пращь Інституту психологї імені Г. С. Костюка НАПН Украӥни / за ред. С.Д. Максименка.Т. ХІІІ, част. 3. К. $211-219$.

13. Лапіна, Т., 2011. Формування економічного мислення у студентівфахівців економічного профілю. Нова педагогічна думка. Науково-методичний журнал. $1.55-58$.

14. Олексенко, Р., 2013. Підготовка і перепідготовка кадрів у системі економічної освіти. Вища освіта України. 2. 59-67.

15. Олексенко, Р. І., 2019. Філософія ринкових відносин: навчальнометодичний посібник. Мелітополь: ФОП Однорог Т.B. 311.

16. Олексенко, Р. Економічна освіта в системі підготовки особистості до самостійного життя та творчості [Електронний ресурс].- Доступний 3 http://www.ird.npu.edu.ua/files/oleksenko.pdf

17. Поясюк, Т. Б., 2011. Акмеологічний підхід до психолого-педагогічної підготовки майбутніх економістів. Вісник Луганського національного університету імені Тараса Шевченка (педагогічні науки). № 10 (221), травень, частина 1. 171 - 177.

18. Смерічевська, С. В., 2008. Аксіологія соціальної відповідальності сучасного бізнесу. Вчені записки Університету «КРОК»: Збірник наукових пращь. 18, том $1.166-171$.

19. Філіпенко, А.В., 2009.Готовність молоді до підприємницької діяльності як філософсько-педагогічна проблема. Вісник НТУУ «КПІ». Філософія. Психологія. Педагогіка. 3. 13 - 19.

20. Фурман, Т. Ю., 2011. Результати аналізу сучасного стану сформованості професійної компетентності майбутніх фахівців у галузі економіки та підприємництва. Збірник наукових праць Хмельницького інституту соціальних технологій Університету «Україна» $4.175-178$.

\section{REFERENCES}

1. Volkov, O. G., Zemlyans`ky`j, A. M., Oleksenko, R. I., Ryabenko, Ye. M., 2017. Filosofiya: navchal`ny`j posibny`k-prakty`kum. MDPU imeni Bogdana Xmel`ny`cz`kogo. Melitopol. 272.

2. Voronkova, V. H., 2013. Formy`rovany`e novogo my`rovozzerny`ya, novogo cheloveka, novogo obshhestva budushhego. Antropologichni vy`miry` filosofs 'ky`x doslidzhen`. Dnipropetrovs`k. 3. 79-80.

3. Voronkova, V. H., 2008. Gumanizaciya osvity`, nauky`, polity`ky`, vlady`, suspil`stva // In-t vy`shhoyi osvity` APN Ukrayiny`, Nacz ped. un-t im. M. P. Dragomanova. K.: Vy`d-vo NPU imeni M.P. Dragomanova. 1-2(7). 204-220.

4. Gipters, Z., 2005. Vy`xovannya dilovy`tosti i tvorchosti majbutnix faxivciv ekonomichnogo profilyu. Ridna shkola. 12.49-52. 
5. Gorbulich, I. O., 2011. Formuvannya gotovnosti do dilovogo spilkuvannya u majbutnix marketologiv. Visny`k Lugans`kogo nacional`nogo universy`tetu imeni Tarasa Shevchenka (pedagogichni nauky`). № 15 (226), serpen`, chasty`na II. 176 - 182.

6. Gurova, Yu. S., 2007. Rozvy`tok lyuds`kogo resursu i mizhnarodna konkurentospromozhnist` krayin. Dy`sertaciya na zdobuttya naukovogo stupenya kandy`data ekonomichny`x nauk. Special'nist' 08.05.01 - svitove gospodarstvo i mizhnarodni ekonomichni vidnosy`ny. K., 190.

7. Demby`cz`ka, N., 2008. Social`no-psy`xologichni problemy` ekonomichnoyi socializaciyi molodi. Social na psy`xologiya. 2 (28). $49-59$.

8. Ekonomichna socializaciya molodi: social’no-psy`xologichny`j aspekt, 2008 / zagal`na redakciya V.V.Moskalenko. K.: Ukrayins `ky`j centr polity`chnogo menedzhmentu. 336.

9. Koval`ova, G. M., 2008. Formuvannya profesijny`x yakostej suchasnogo ekonomista osvitnim seredovy`shhem. Naukovi praci Donecz`kogo nacional`nogo texnichnogo universy`tetu. Seriya: Pedagogika, psy`xologiya i sociologiya. Donecz`k: DVNZ «DonNTU». 2 (133). $374-375$.

10. Kremen`, V. M., 2011. Osobly`vosti profesijnoyi diyal’nosti faxivciv z finansiv. Problemy`i perspekty`vy` rozvy`tku bankivs`koyi sy`stemy` Ukrayiny`. Zbirny`k naukovy`x pracz`. Sumy`: DVNZ «Ukrayins `ka akademiya bankivs `koyi spravy`» NBU. 31. 145 - 156.

11. Kuklin, O.V., 2008. Stanovlennya sy`stemy` ekonomichnoyi osvity` v Ukrayini u konteksti Bolons`kogo procesu. Visny`k Cherkas`kogo universy`tetu. Naukovy`j zhurnal. Seriya: Pedagogichni nauky`. Cherkasy`: ChNU imeni Bogdana Xmel`ny`cz`kogo. 120. 127 133.

12. Lavrenko, O. V., 2011. Ekonomichni nastanovlennya yak chy`nny`k stanovlennya sub'yekta ekonomichnoyi socializaciyi. Problemy zagal’noyi ta pedagogichnoyi psy`xologiyi. Zbirny`k naukovy`x pracz`Insty`tutu psy`xologiyi imeni G.S. Kostyuka NAPN Ukrayiny` / Za red. S. D. Maksy`menka.T. XIII, chast. 3. K. P. $211-219$.

13.Lapina, T., 2011. Formuvannya ekonomichnogo my`slennya u studentiv-faxivciv ekonomichnogo profilyu. Nova pedagogichna dumka. Naukovo-metody`chny`j zhurnal. 1. 55 -58 .

14. Oleksenko, R., 2013. Pidgotovka i perepidgotovka kadriv u sy`stemi ekonomichnoyi osvity. Vy`shha osvita Ukrayiny`. 2. 59-67.

15. Oleksenko, R. I. , 2019. Filosofiya ry`nkovy`x vidnosy`n: navchal`no-metody`chny`j posibny`k. Melitopol`: FOP Odnorog T.V. 311.

16. Oleksenko, R. Ekonomichna osvita v sy`stemi pidgotovky` osoby`stosti do samostijnogo zhy`ttya ta tvorchosti [Elektronny` $j$ resurs]. - Dostupny` $j \mathrm{z}$ http://www.ird.npu.edu.ua/files/oleksenko.pdf

17. Poyasyuk, T. B., 2011. Akmeologichny`j pidxid do psy`xologo-pedagogichnoyi pidgotovky` majbutnix ekonomistiv. Visny`k Lugans`kogo nacional`nogo universy`tetu imeni Tarasa Shevchenka (pedagogichni nauky`). № 10 (221), traven`, chasty`na 1. P. 171 - 177.

18. Smerichevs`ka, S.V., 2008. Aksiologiya social’noyi vidpovidal’nosti suchasnogo biznesu. Vcheni zapy`sky`Universy ‘tetu «KROK»: Zbirny`k naukovy`x pracz'. 18, tom 1. 166 $-171$.

19. Filipenko, A. V. , 2009. Gotovnist` molodi do pidpry`yemny`cz`koyi diyal’nosti yak filosofs`ko-pedagogichna problema. Visny`k NTUU «KPI». Filosofiya. Psy`xologiya. Pedagogika. Vy`pusk $3.13-19$.

20. Furman, T. Yu., 2011. Rezul'taty analizu suchasnogo stanu sformovanosti profesijnoyi kompetentnosti majbutnix faxivciv u galuzi ekonomiky` ta pidpry`yemny`cztva. Zbirny`k naukovy`x pracz`Xmel`ny`cz`kogo insty`tutu social`ny`x texnologij Universy`tetu «Ukrayina». $4.175-178$.

Position and role of modern economic education as the main megatrend of innovative development of Ukraine 
ОЛЕКСЕНКО, Р. І. - доктор філософських наук, професор, професор кафедри публічного управління та права, Таврійський державний агротехнологічний університет (Мелітополь, Україна)

E-mail: roman.xdsl@ukr.net,

ORCID iD: https://orcid.org/ 0000-0002-2171-514X

\section{МІСЦЕ І РОЛЬ СУЧАСНОЇ ЕКОНОМІЧНОЇ ОСВІТИ ЯК ГОЛОВНОГО МЕГАТРЕНДУ ІННОВАЦЙНОГО РОЗВИТКУ УКРАЇНИ}

\section{Анотація.}

Актуальність дослідження полягає у системному осмисленні та стратегічному вирішенні проблем, пов'язаних з економічною освітою сучасної молоді. В умовах цифровізації для нашої країни є головним в підготовці висококваліфікованих кадрів для реального сектору економіки - формування готовності молоді до адаптації в умовах соціально-економічного швидкозмінного світу. Ця проблема може бути вирішена за умови формування та розвитку у молоді підприємницьких здібностей, які забезпечуватимуть досягнення реальних успіхів у будь-якій області обраної ними професійної діяльності. Метою статті є визначення місця і ролі економічної освіти як головного мегатренду інноваційного розвитку України. Завданнями дослідження с: 1) дослідити феномен людини економічної та ії роль в сучасному житті країни; 2) виявити проблемні складові компоненти освіти при формуванні ринкової свідомості молоді; 3) запропонувати шляхи розвитку вітчизняної економічної освіти при формуванні креативної економічної освіти і культури сучасної молоді. Методологія дослідження. В результаті дослідження цієї проблеми використовувалися: діалектичний, абстрактнологічний, монографічний та інші методи наукового дослідження. Специфічна методологія аналізу освіти дала поштовх до зародження наукової традиції розглядати освіту як фактор суспільних трансформацій. Результати дослідження. Загальна та професійна економічна освіта сьогодні для будь-якого суспільства, особливо трансформаційного, є ключовим фактором забезпечення його інноваційного розвитку в рамках новітніх загальносвітових глобальних тенденцій. Це, в свою чергу, актуалізує проблему диверсифікації та урізноманітнення форм, методів та організаційних форм надання громадянам України високоякісних освітніх послуг у сфері економічних наук та навчальних дисциплін. Розвиток економічної системи вітчизняного національного суспільства прямо залежить від того, чи в змозі українська освітня спільнота виробити адекватні механізми формування у молоді високого рівня економічної та підприємницької культури сучасного типу. В той же час, і реальні економічні процеси, безумовно, впливають на економічну соціалізацію молоді та рівень іiі економічнопідприємницької освіченості та вихованості.

Ключові слова: економічна освіта, економічна свідомість, креативність, культура, інноваційний розвиток, підприємець.

ОЛЕКСЕНКО, Р. И. - доктор философских наук, профессор, профессор кафедры публичного управления и права, Таврический государственный агротехнологический университет (Мелитополь, Украина)

E-mail: roman.xdsl@ukr.net,

ORCID iD: https://orcid.org/ 0000-0002-2171-514X 


\title{
МЕСТО И РОЛЬ СОВРЕМЕННОГО ЭКОНОМИЧЕСКОГО ОБРАЗОВАНИЯ КАК ГЛАВНОГО МЕГАТРЕНДА ИННОВАЦИОННОГО РАЗВИТИЯ УКРАИНЫ
}

\begin{abstract}
Аннотация.
Актуальность исследования заключается в системном осмыслении и стратегическом решении проблем, связанных с экономическим образованием современной молодежи. В условиях цифровизации, для нашей страны, является главным в подготовке высококвалифицированных кадров для реального сектора экономики - формирование готовности молодежи к адаптации в условиях социальноэкономического быстро изменяющегося мира. Эта проблема может быть решена при условии формирования и развития у молодежи предпринимательских способностей, обеспечивающих достижение реальных успехов в любой области выбранной ими профессиональной деятельности. Целью статьи является определение места и роли экономического образования как главного мегатренда инновационного развития Украины. Задачами исследования являются: 1) исследовать феномен человека экономического и ее роль в современной жизни страны; 2) выявить проблемные компоненты образования при формировании рыночного сознания молодежи; 3) предложить пути развития отечественного экономического образования при формировании креативного экономического образования и культуры современной молодежи. Методология исследования. В результате исследования этой проблемы использовались: диалектический, абстрактно-логический, монографический и другие методы научного исследования. Специфическая методология анализа образования дала толчок к зарождению научной традиции рассматривать образование как фактор общественных трансформаций. Результаты исследования. Общее и профессиональное экономическое образование сегодня для любого общества, особенно трансформационного, является ключевым фактором обеспечения его инновационного развития в рамках новейших общемировых глобальных тенденций. Это, в свою очередь, актуализирует проблему диверсификации и разнообразие форм, методов и организационных форм оказания гражданам Украины высококачественных образовательных услуг в сфере экономических наук и учебных дисциплин. Развитие экономической системы отечественного национального общества напрямую зависит от того, в состоянии ли украинское образовательное сообщество выработать адекватные механизмы формирования у молодежи высокого уровня экономической и предпринимательской культуры современного типа. В то же время, и реальные экономические процессы, безусловно, влияют на экономическую социализацию молодежи и уровень ее экономически предпринимательской образованности и воспитанности.
\end{abstract}

Ключевые слова: экономическое образование, экономическое сознание, креативность, культура, инновационное развитие, предприниматель.

Received date 10.02.2020

Accepted date 15.02.2020

Published date 18.02.2020

Position and role of modern economic education as the main megatrend of innovative development of Ukraine 